\title{
Fluctuation of potential zinc status biomarkers throughout a reproductive cycle of primiparous and multiparous sows
}

\author{
Miriam M. J. van Riet ${ }^{1,2 *}$, Sam Millet ${ }^{1}$, Elena Nalon ${ }^{1,3}$, Karolien C. M. Langendries ${ }^{1,2}$, An Cools ${ }^{2}$, \\ Bart Ampe $^{1}$, Gijs Du Laing ${ }^{4}$, Frank A. M. Tuyttens ${ }^{1,2}$, Dominiek Maes ${ }^{3}$ and Geert P. J. Janssens ${ }^{2}$ \\ ${ }^{1}$ Animal Sciences Unit, Institute for Agricultural and Fisheries Research (ILVO), Scheldeweg 68, 9090 Melle, Belgium \\ ${ }^{2}$ Department of Nutrition, Genetics and Ethology, Faculty of Veterinary Medicine, Ghent University, Merelbeke, Belgium \\ ${ }^{3}$ Department of Obstetrics, Reproduction and Herd Health, Faculty of Veterinary Medicine, Ghent University, Merelbeke, \\ Belgium \\ ${ }^{4}$ Laboratory of Analytical Chemistry and Applied Ecochemistry, Faculty of Bioscience Engineering, Ghent University, \\ Ghent, Belgium
}

(Submitted 19 August 2014 - Final revision received 19 May 2015 - Accepted 22 May 2015 - First published online 22 July 2015)

\section{Abstract}

Fluctuations in $\mathrm{Zn}$ metabolism throughout gestation and lactation might affect $\mathrm{Zn}$ requirements. However, scientific data on $\mathrm{Zn}$ requirements for breeding sows are limited. The objective of the present study was to assess the $\mathrm{Zn}$ status of primiparous and multiparous sows using different $\mathrm{Zn}$ status biomarkers, to identify periods of critical $\mathrm{Zn}$ status throughout the reproductive cycle at different parities. Blood samples were taken after overnight fasting before feeding in the morning from five primiparous and ten multiparous sows at fixed time intervals during gestation (days - 5, 0 (insemination), 21, 42, 63 and 84), around parturition (days 108, 112, 115 (parturition) and 118) and during lactation (days 122, 129 and 143 (weaning)). At parturition, blood samples were collected from two randomly selected piglets per sow before colostrum intake. Plasma was analysed for $\mathrm{Zn}$ and $\mathrm{Cu}$ contents, whereas serum was analysed for alkaline phosphatase, metallothionein and albumin concentrations. Independently of parity, all biomarkers fluctuated differently during gestation and lactation $(P<0 \cdot 050)$. This reflects their different roles in $\mathrm{Zn}$ metabolism, and suggests that the choice of a $\mathrm{Zn}$ status biomarker necessitates careful consideration. Low average plasma $\mathrm{Zn}$ concentration at the end of gestation and throughout lactation seem to be replenished towards weaning.

\section{Key words: Serum alkaline phosphatase: Serum metallothionein: Plasma zinc: Serum albumin}

Fluctuations in $\mathrm{Zn}$ metabolism throughout the reproductive cycle of sows are a result of physiological processes during gestation and lactation to support fetal growth and development and milk synthesis ${ }^{(1-4)}$.

In particular, placental $\mathrm{Zn}$ transport, luminal $\mathrm{Zn}$ absorption and $\mathrm{Zn}$ mobilisation from the bone and liver are increased at the end of gestation and lactation ${ }^{(2-4)}$. This results in varying $\mathrm{Zn}$ transport and a changed role of transport proteins in both the fetus and the dam ${ }^{(5)}$, thereby increasing the dietary $\mathrm{Zn}$ requirement.

Inadequate intake of dietary $\mathrm{Zn}$ during gestation and lactation may cause reproductive failures, without clinical signs of maternal $\mathrm{Zn}$ deficiency ${ }^{(6-8)}$ : the sow depletes her body $\mathrm{Zn}$ reserves in tissues and fluids before litter size, fetal development or milk composition are affected ${ }^{(1,6-8)}$. Scientific data of $\mathrm{Zn}$ requirements for sows are limited. Therefore, adequately measuring $\mathrm{Zn}$ status is critical, albeit difficult ${ }^{(9-11)}$.
Zn status may be reflected by biochemical markers (i.e. biomarkers), which are related to the structural, regulatory and catalytic role of $\mathrm{Zn}$. Plasma $\mathrm{Zn}$ is the most frequently used biomarker for $\mathrm{Zn}$ status. However, plasma $\mathrm{Zn}$ alone shows limitations if study conditions are not controlled or if confounding factors are present ${ }^{(12)}$. These confounding factors may be infection or diseases, an acute-phase response, stress, feeding state (fasted or postprandial measures), reproductive phase (gestation), and also the method of blood collection, and concomitant blood sample transport, storage and analysis ${ }^{(11,13,14)}$. Other biomarkers such as albumin, metallothionein (MT) and alkaline phosphatase (ALP) play a role in $\mathrm{Zn}$ metabolism and homeostasis: $\mathrm{Zn}$ is bound to albumin after absorption ${ }^{(15,16)}$; MT (a small cysteine-rich protein) is involved in regulating the quantity of $\mathrm{Zn}$ absorbed ${ }^{(15,17,18)}$; ALP is a $\mathrm{Zn}$-dependent enzyme in which $\mathrm{Zn}$ ions are present in the active centre of the enzyme ${ }^{(19)}$. Together, they may be

Abbreviations: ALP, alkaline phosphatase; MT, metallothionein.

*Corresponding author: M. M. J. van Riet, fax +3292722601, email miriam.vanriet@ilvo.vlaanderen.be 
useful to assess the body's response to Zn supplementation or depletion. To our knowledge, the normal fluctuation of these biomarkers throughout the reproductive cycle of sows has not yet been determined.

The objective of the present study was to assess the $\mathrm{Zn}$ status of primiparous and multiparous sows using different $\mathrm{Zn}$ status biomarkers, to identify periods of critical $\mathrm{Zn}$ status throughout the reproductive cycle at different parities.

\section{Materials and methods \\ Animals and diets}

The experiment was performed on one group of twenty-three commercial hybrid sows (RA-SE Genetics) from the Institute for Agricultural and Fisheries Research (ILVO). However, one sow was too stressed during blood sampling and therefore excluded from the experiment. Furthermore, four sows were not gravid and three primiparous sows aborted at days 58, 66 and 93 of gestation, and therefore they were not included in the analysis. One primiparous sow developed an abscess under the cheek and required veterinary treatment. This sow remained in the experimental group, because her results were not considered outliers compared with other sows. Consequently, the experiment included ten multiparous and five primiparous sows from one group that were followed during one reproductive cycle. The multiparous sows (parity ranged between two and eleven) weighed 234 (SD 36) kg at weaning of the preceding lactation period (i.e. at the start of the study, day -5). The primiparous sows (gilts, 233 (SD 12) d old at insemination) weighed 142 (SD 7) $\mathrm{kg}$ at day -5 .

The sows were all housed individually during the first 4 weeks of gestation and from 1 week before parturition until weaning. During mid- and end gestation, the sows were housed as one group using an automated feeding system with individual sow recognition through an electronic transponder in the sow's ear.

The sows were fed a gestation diet and a lactation diet according to commercial dietary standards and nutrient requirements $^{(20)}$ (Tables 1 and 2). Feed samples of the gestation and lactation diet were subject to proximate analysis according to international standard methods accredited by ISO 17025 . The gestation diet was provided from the start of the study until 1 week before parturition, whereas the lactation diet was provided 1 week before parturition until weaning. During the first 4 weeks of gestation, the sows were fed twice daily, in total $2.3 \mathrm{~kg}$. During mid- and end gestation, the sows were fed $2.6 \mathrm{~kg} / \mathrm{d}$. During lactation, $0 \cdot 25 \mathrm{~kg}$ of feed per piglet was gradually supplemented in addition to $3 \mathrm{~kg}$ feed, provided in two equal portions daily (e.g. a sow with twelve piglets received $6 \mathrm{~kg}$ of feed daily). There were no feed leftovers. Throughout the experiment, all sows had ad libitum access to drinking-water, except in the first 4 weeks of gestation, in which water was automatically provided through nipple drinkers for $15 \mathrm{~min}$ every hour and for $45 \mathrm{~min}$ while feeding in order to prohibit water spillage.

\section{Experimental design}

Blood samples were taken before feeding in the morning (between 08.00-10.00 hours), after overnight fasting (17.5 h), at fixed time intervals throughout one reproductive cycle: day -5 (weaning of the preceding cycle for multiparous sows; 'start of the study in December 2011'); throughout gestation (days 0 (insemination), 21, 42, 63 and 84); around parturition (days 108, 112, 115 (parturition) and 118); during lactation (days 122, 129 and 143 (weaning)). The days until parturition were predicted from the expected date of parturition (based on a gestation period of $115 \mathrm{~d}$ ), whereas from parturition onwards, the sows were sampled based on the date of parturition. Blood samples were collected from the jugular vein using stainless-steel needles and plastic syringes, and added to one heparin and one serum vacuum tube (Terumo Europe). At parturition, two piglets per sow were randomly selected for blood sampling from the jugular vein before colostrum intake, and the blood sample was added to one heparin vacuum tube (Terumo Europe).

Within $1 \mathrm{~h}$ after the first piglet was born, colostrum was collected. At 1 week after parturition, milk samples were also collected using $1 \mathrm{ml}$ oxytocin ( $17 \mu \mathrm{g}$ oxytocin/ml; VMD N.V.) to stimulate milk release. The colostrum and milk samples were collected from all nipples from either the left or right side of the udder, repeatedly from front to back nipples, until $20 \mathrm{ml}$ were collected. At weaning, reproductive performances were documented, taking into account

Table 1. Ingredient composition of the gestation and lactation diets

\begin{tabular}{|c|c|c|}
\hline Ingredients $(\mathrm{g} / \mathrm{kg})$ & Gestation diet & Lactation diet \\
\hline Beet pulp & $150 \cdot 0$ & $30 \cdot 0$ \\
\hline Wheat & $150 \cdot 0$ & - \\
\hline Wheat bran & $120 \cdot 0$ & $49 \cdot 0$ \\
\hline Barley & $150 \cdot 0$ & $107 \cdot 6$ \\
\hline Maize & $125 \cdot 7$ & 350.0 \\
\hline Rye & - & $100 \cdot 0$ \\
\hline Alfalfa meal & $60 \cdot 8$ & 80.0 \\
\hline Soyabeans heated & $104 \cdot 2$ & 23.3 \\
\hline Soyabean meal & - & $156 \cdot 7$ \\
\hline Soyabean oil & $1 \cdot 7$ & - \\
\hline Rapeseed meal & $70 \cdot 0$ & - \\
\hline Beet molasses & $40 \cdot 0$ & $30 \cdot 0$ \\
\hline Premix 1\%* & $10 \cdot 0$ & $10 \cdot 0$ \\
\hline Benzoic acid & - & $5 \cdot 0$ \\
\hline Limestone & 8.5 & $12 \cdot 2$ \\
\hline Calcium monophosphate & $3 \cdot 3$ & $13 \cdot 2$ \\
\hline Lard & - & $22 \cdot 3$ \\
\hline Salt & $5 \cdot 0$ & 4.3 \\
\hline L-Lys HCl & 0.7 & $2 \cdot 8$ \\
\hline L-Thr & 0.1 & 1.6 \\
\hline L-Val & - & $1 \cdot 2$ \\
\hline DL-Met & - & 0.4 \\
\hline L-Trp & - & 0.3 \\
\hline Phytase & 0.1 & 0.1 \\
\hline
\end{tabular}

*Premix $1 \%$ included per kg diet: vitamin $A, 4.08 \mathrm{mg}$; vitamin $D_{3}, 0.05 \mathrm{mg}$; vitamin $E, 75.0 \mathrm{mg}$; vitamin $\mathrm{K}_{3}, 1.01 \mathrm{mg}$; vitamin $B_{1}, 1.5 \mathrm{mg}$; vitamin $B_{2}, 5.0 \mathrm{mg}$; vitamin $B_{5}, 18.0 \mathrm{mg}$; vitamin $B_{6}, 4.0 \mathrm{mg}$; vitamin $B_{12}, 0.03 \mathrm{mg}$; vitamin $B_{3}$, $25.0 \mathrm{mg}$; vitamin $\mathrm{B}_{11}, 3.0 \mathrm{mg}$; biotin, $0.3 \mathrm{mg}$; choline, $432.5 \mathrm{mg}$; $\mathrm{Fe}$ as $\mathrm{FeSO}_{4}$. $\mathrm{H}_{2} \mathrm{O}, 150.0 \mathrm{mg} ; \mathrm{Cu}$ as $\mathrm{CuSO}_{4} \cdot 5 \mathrm{H}_{2} \mathrm{O}, 16.43 \mathrm{mg} ; \mathrm{Mn}$ as $\mathrm{MnO}, 50.0 \mathrm{mg} ; \mathrm{Zn}$ as $\mathrm{ZnO}, 92.97 \mathrm{mg}$; I as $\mathrm{Ca}\left(\mathrm{IO}_{3}\right)_{2}, 2.0 \mathrm{mg}$; Se as $\mathrm{Na}_{2} \mathrm{O}_{3} \mathrm{Se}, 0.40 \mathrm{mg}$; $\mathrm{Ca}, 0.89 \mathrm{mg}$; $\mathrm{P}, 0.05 \mathrm{mg}$; Mg, $0.16 \mathrm{mg}$; Na, 3.02 mg; Cl, $0.12 \mathrm{mg} ; \mathrm{K}, 0.08 \mathrm{mg} ; \mathrm{S}, 0.11 \mathrm{mg}$; lysine $0.04 \mathrm{mg}$; methionine, $0.01 \mathrm{mg}$; threonine, $0.03 \mathrm{mg}$; tryptophan, $0.01 \mathrm{mg}$; butylhydroxytoluene, $0.50 \mathrm{mg}$; ethoxyquine, $0.55 \mathrm{mg}$; butylated hydroxyanisol, $0.05 \mathrm{mg}$. 
Table 2. Analysed and calculated* nutrient composition of the gestation and lactation diets

\begin{tabular}{|c|c|c|}
\hline Chemical analysis $(\mathrm{g} / \mathrm{kg})$ & Gestation diet & Lactation diet \\
\hline DM & $885 \cdot 6$ & $893 \cdot 2$ \\
\hline Crude ash & $58 \cdot 1$ & $62 \cdot 1$ \\
\hline Crude protein & 151 & 164.9 \\
\hline Crude fat & $51 \cdot 3$ & $55 \cdot 7$ \\
\hline Starch & $295 \cdot 6$ & $355 \cdot 1$ \\
\hline Sugar & $63 \cdot 1$ & $58 \cdot 6$ \\
\hline ADF & $86 \cdot 3$ & 55.9 \\
\hline NDF & $182 \cdot 7$ & $122 \cdot 6$ \\
\hline$A D L$ & $14 \cdot 3$ & $8 \cdot 3$ \\
\hline $\mathrm{Ca}$ & 9.5 & $12 \cdot 1$ \\
\hline $\mathrm{P}$ & 4.7 & $6 \cdot 0$ \\
\hline $\mathrm{Cu}(\mathrm{mg} / \mathrm{kg})$ & $19 \cdot 9$ & $24 \cdot 8$ \\
\hline Zn (mg/kg) & $124 \cdot 2$ & 124.5 \\
\hline ID Lys & $5 \cdot 2$ & 7.9 \\
\hline ID Met & 1.8 & $2 \cdot 3$ \\
\hline ID Thr & 3.4 & 5.5 \\
\hline ID Trp & 1.2 & 1.6 \\
\hline ID Arg & $6 \cdot 7$ & $8 \cdot 1$ \\
\hline ID Leu & $7 \cdot 8$ & $10 \cdot 0$ \\
\hline ID lle & 3.9 & 4.8 \\
\hline ID His & $2 \cdot 8$ & 3.2 \\
\hline ID Val & 4.7 & $6 \cdot 7$ \\
\hline ID Phe & 4.7 & $6 \cdot 0$ \\
\hline NEv (MJ/kg) & $8 \cdot 6$ & $9 \cdot 2$ \\
\hline
\end{tabular}

ADF, acid-detergent fibre; NDF, neutral-detergent fibre; ADL, acid-detergent lignin; ID, ileal digestible; NEv, net energy for pigs.

* Chemical analyses of ID amino acids and NEv (NEv is calculated according to the feed tables of the Centraal Veevoederbureau (the Netherlands), 2007).

cross-fostering and provision of creep feed (transitional feed) to the piglets from day 10 postpartum.

Body weight and back-fat thickness were measured at the start of the study (i.e. weaning of the preceding lactation period for the multiparous sows (day -5)), at days 63, 84 and 108 of gestation, and at weaning (day 143). Back-fat thickness was measured between the $3 \mathrm{rd}$ and 4 th last rib, $7 \mathrm{~cm}$ at the left and right side of the vertebrae (P2). After P2 was lubricated, back-fat measurements were repeated three times, alternately at the left and right side (PIGLOG 105; SFK Technology). The average thickness was used for further calculations.

The present observational study was conducted according to the institutional and national guidelines for the care and use of animals, and all experimental procedures involving these animals were approved by the ILVO's ethical committee for animal experiments.

\section{Preparation of blood samples}

A heparinised blood sample $(1 \mathrm{ml})$ was used for haematocrit assay and centrifuged at $2749 \mathrm{~g}$ for $30 \mathrm{~min}$ at $20^{\circ} \mathrm{C}$. The remainder was centrifuged at $1500 \mathrm{~g}$ for $10 \mathrm{~min}$ at $4^{\circ} \mathrm{C}$, divided over different $5 \mathrm{ml}$ disposable polystyrene tubes, and stored for $24 \mathrm{~h}$ at $-20^{\circ} \mathrm{C}$, thereafter at $-80^{\circ} \mathrm{C}$ until analysis. Plasma was analysed for $\mathrm{Zn}$ and $\mathrm{Cu}$ concentrations.

After overnight incubation at $4^{\circ} \mathrm{C}$, serum was separated by centrifugation at $1500 \mathrm{~g}$ for $10 \mathrm{~min}$ at $4^{\circ} \mathrm{C}$ and stored for $24 \mathrm{~h}$ at $-20^{\circ} \mathrm{C}$, thereafter at $-80^{\circ} \mathrm{C}$ until analysis. Serum was analysed for ALP, albumin and MT concentrations. Colostrum, milk and the piglets' plasma were analysed for $\mathrm{Zn}$ and $\mathrm{Cu}$ concentrations. Plasma $\mathrm{Cu}$ concentration was not measured as a $\mathrm{Zn}$ status biomarker; however, because it uses some of the same transporter mechanisms, it may provide information on the affected pathways ${ }^{(15,18,21,22)}$

\section{Analysis of zinc status biomarkers}

Plasma samples were deproteinated (Randox ZN2607; Randox Laboratories Limited) by mixing with an equal volume of TCA and centrifuged at $10000 \mathrm{~g}$ for $10 \mathrm{~min}$. The remaining supernatant was used within $2 \mathrm{~h}$ to determine plasma $\mathrm{Zn}$ and $\mathrm{Cu}$ concentrations.

For plasma $\mathrm{Zn}$ analysis, the deproteinated plasma was diluted five times with a colour reagent (Randox Kit, ZN2341; Randox Laboratories Limited), and incubated for $5 \mathrm{~min}$ at $25^{\circ} \mathrm{C}$. Absorbance was measured at a wavelength of $570 \mathrm{~nm}$ with a reference wavelength of $620 \mathrm{~nm}$ using a microplate reader (EZ reader 400; Biochrom Limited). Plasma Zn concentration was interpolated from the standard multipoint calibration curve. The inter- and intra-assay CV were $2 \cdot 19$ and $3.61 \%$, respectively. For quality control, pooled porcine plasma samples were spiked using $\mathrm{ZnCl}_{2}$ to calculate the rate of $\mathrm{Zn}$ recovery. The regression line of the calibration curve to compare the measured and expected $\mathrm{Zn}$ concentrations was as follows: $y=0.0003 x+0.0252, R^{2} 0.9966$. The minimum and maximum recovery rates were 99.5 and $119.8 \%$, respectively.

For plasma Cu analysis, a reagent (Randox Kit, CU2340; Randox Laboratories Limited) was added to the deproteinated plasma, and this solution was incubated for $60 \mathrm{~s}$ at $37^{\circ} \mathrm{C}$ (Memmert Elanco incubation oven; Memmert $\mathrm{GmbH}$ ). Absorbance was measured at a wavelength of $580 \mathrm{~nm}$ (Ultrospec IIE; LKB Biochrom Limited). A colour reagent was added and the solution was mixed. After $5 \mathrm{~min}$ of incubation at $37^{\circ} \mathrm{C}$,

Table 3. Body weight and back-fat thickness throughout the reproductive cycle of sows ( $n 15$; five primiparous and ten multiparous sows)

(Mean values with their standard errors)

\begin{tabular}{|c|c|c|c|c|c|c|c|c|}
\hline \multirow{3}{*}{$\begin{array}{l}\text { Cycle } \\
\text { Day* }\end{array}$} & \multicolumn{4}{|c|}{ Body weight (kg) } & \multicolumn{4}{|c|}{ Back-fat thickness (mm) } \\
\hline & \multicolumn{2}{|c|}{ Primiparous } & \multicolumn{2}{|c|}{ Multiparous } & \multicolumn{2}{|c|}{ Primiparous } & \multicolumn{2}{|c|}{ Multiparous } \\
\hline & Mean & SE & Mean & SE & Mean & SE & Mean & SE \\
\hline-5 & $142^{\mathrm{a}, \mathrm{A}}$ & 3 & $234^{\mathrm{a}, \mathrm{B}}$ & 11 & $18^{\mathrm{a}}$ & 2 & $18^{a, b}$ & 1 \\
\hline 63 & $188^{\mathrm{b}, \mathrm{A}}$ & 4 & $250^{\mathrm{b}, \mathrm{B}}$ & 11 & $21^{a, b}$ & 2 & $19^{\mathrm{a}}$ & 2 \\
\hline 84 & $203^{\mathrm{c}, \mathrm{A}}$ & 6 & $269^{c, B}$ & 11 & $21^{a, b}$ & 1 & $19^{\mathrm{a}}$ & 1 \\
\hline 108 & $223^{\mathrm{d}, \mathrm{A}}$ & 6 & $279^{\mathrm{d}, \mathrm{B}}$ & 11 & $23^{b}$ & 1 & $18^{\mathrm{a}}$ & 1 \\
\hline 143 & $169^{\mathrm{e}, \mathrm{A}}$ & 6 & $237^{\mathrm{a}, \mathrm{B}}$ & 10 & $14^{\mathrm{c}}$ & 1 & $15^{\mathrm{b}}$ & 2 \\
\hline \multicolumn{9}{|l|}{$P$} \\
\hline Day & \multicolumn{4}{|c|}{$<0.001$} & \multicolumn{4}{|c|}{$<0.001$} \\
\hline Parity & \multicolumn{4}{|c|}{$<0.001$} & \multicolumn{4}{|c|}{0.373} \\
\hline $\mathrm{D} \times \mathrm{P} \dagger$ & \multicolumn{4}{|c|}{$<0.001$} & \multicolumn{4}{|c|}{0.117} \\
\hline
\end{tabular}

${ }^{\mathrm{a}, \mathrm{b}}$ Mean values within a column with unlike superscript letters were significantly different between different days of the reproductive cycle $(P<0.050)$.

$\mathrm{A}, \mathrm{B}$ Mean values within a row with unlike superscript letters were significantly different between the primiparous and multiparous sows for the specific day of the reproductive cycle $(P<0.050)$.

* Day -5 represents the start of the study, days 63,84 and 108 represent gestation and day 143 represents weaning.

† Interaction between day $(D)$ and parity $(P)$. 
Table 4. Reproductive performance of primiparous $(n 5)$ and multiparous $(n 10)$ sows $^{\star}$

(Mean values with their standard errors)

\begin{tabular}{|c|c|c|c|c|c|}
\hline & \multicolumn{2}{|c|}{ Primiparous } & \multicolumn{2}{|c|}{ Multiparous } & \multirow[b]{2}{*}{$P$} \\
\hline & Mean & SE & Mean & SE & \\
\hline Piglets born alive $(n)$ & $13 \cdot 0$ & $1 \cdot 2$ & $13 \cdot 0$ & 0.9 & 0.741 \\
\hline Stillborn piglets $(n)$ & 1.0 & 0.4 & 1.0 & 0.4 & 0.537 \\
\hline $\begin{array}{l}\text { Average body weight of } \\
\text { piglets born alive }(\mathrm{kg})\end{array}$ & 1.3 & 0.1 & 1.5 & 0.1 & 0.210 \\
\hline Piglet mortality (\%) & $13 \cdot 0$ & 5.8 & $10 \cdot 0$ & $2 \cdot 4$ & 0.537 \\
\hline Weaned piglets $(n)$ & 11.0 & 0.9 & $12 \cdot 0$ & 0.9 & 0.480 \\
\hline $\begin{array}{l}\text { Average body weight of } \\
\text { weaned piglets }(\mathrm{kg})\end{array}$ & 8.9 & 0.2 & 8.4 & 0.2 & 0.153 \\
\hline
\end{tabular}

* No significant differences were found between the primiparous and multiparous sows $(P>0.050)$

absorbance was measured at the same wavelength. Plasma $\mathrm{Cu}$ concentration was interpolated from the standard multipoint calibration curve. The inter-assay CV was $2 \cdot 83 \%$. For quality control, pooled porcine plasma samples were spiked using $\mathrm{CuCl}_{2} \cdot 2\left(\mathrm{H}_{2} \mathrm{O}\right)$ to calculate the rate of $\mathrm{Cu}$ recovery. The regression line of the calibration curve to compare the measured and expected $\mathrm{Cu}$ concentrations was as follows: $y=0.0006 x+0.0806, R^{2} 0.9912$. The minimum and maximum recovery rates were 96.4 and $103.7 \%$, respectively.

Albumin was determined colorimetrically (Cobas Integra Albumin Gen.2; Roche Diagnostics $\mathrm{GmbH}$ ), by binding to an anionic dye (bromocresol green) to form a blue-green complex. The total albumin concentration was proportional to the colour intensity and determined by an increase in absorbance at $583 \mathrm{~nm}$. Serum albumin concentrations were within the expected range of the kit $(3-96 \mathrm{~g} / \mathrm{l})$, and the recovery rate was within $10 \%$ of the initial value at an albumin concentration of $35 \mathrm{~g} / \mathrm{l}$. The observed albumin concentrations were daily controlled using an independent human control serum with a high and low known concentration.

MT was determined using competitive ELISA (Porcine Metallothionein (MET) Elisa Kit, E07M0030; BlueGene Biotech Company), including duplicate standards and controls from human origin for each run. The product of the enzyme-substrate reaction forms a blue-coloured complex and turns into yellow after the reaction was stopped by adding a stop solution. The intensity of the colour was measured spectrophotometrically at $450 \mathrm{~nm}$ (BEP 2000; Siemens AG). MT concentration was interpolated from the standard curve. The certificate of analysis reported an inter- and intra-assay CV of $6 \cdot 6-8.2 \%$ and $4.4-5.6 \%$, respectively. The recovery rates ranged between 94 and $103 \%$.

ALP concentration was determined colorimetrically (Cobas c systems ALP2; Roche Diagnostics $\mathrm{GmbH}$ ). In the presence of $\mathrm{Mg}$ and $\mathrm{Zn}, p$-nitrophenyl phosphate was cleaved into phosphate and $p$-nitrophenol. The released $p$-nitrophenol was directly proportional to the catalytic ALP activity, which is determined by an increase in absorbance at $480 / 450 \mathrm{~nm}$. The device was calibrated with a known concentration before the analysis to measure the concentration of ALP. Serum ALP concentrations were within the expected range of the kit (5-1200 units/1), and the recovery rate was within
$10 \%$ of the initial value at an ALP concentration of 100 units/l. The observed ALP concentrations were daily controlled using an independent human control serum with a high and low known concentration.

\section{Concentration of zinc and copper in colostrum and milk}

Colostrum and milk samples $(1.5 \mathrm{~g})$ were digested in a microwave oven (MarsX; CEM), using $\mathrm{HNO}_{3} / \mathrm{H}_{2} \mathrm{O}_{2}$, and analysed for $\mathrm{Zn}$ and $\mathrm{Cu}$ concentrations by inductively coupled plasma optical emission spectrometry (ICP-OES, Vista MPX; Varian, Inc.). For quality control, two cows' milk samples were spiked, both with 50 and $100 \mu \mathrm{g} / \mathrm{l}$ of $\mathrm{Cu}$ and $\mathrm{Zn}$. The recovery rates of spiked $\mathrm{Cu}$ and $\mathrm{Zn}$ varied between 81.2 and $88.9 \%$, and between 83.7 and $91.2 \%$, respectively.

\section{Statistical analysis}

The evolution over time during gestation (period between day 0 (insemination) and day 115 (parturition)) and lactation (period between day 118 and day 143 (weaning)) of all biomarkers were analysed using a linear mixed model for each reproductive phase (gestation and lactation), with the biomarker as the outcome and parity, haematocrit, time, interaction between parity and time, and a quadratic time effect as fixed effects. Inclusion of a quadratic time effect allows the identification of a non-linear evolution over time. In case of repeated measures, a random effect for sows was introduced in the model.

Biomarkers in colostrum, milk and the piglets' plasma were analysed using a linear mixed model, with the biomarker as the outcome and all sows' biomarkers at parturition or the average during gestation, and parity as fixed effects. The non-significant biomarkers were removed from the model. Sow was introduced as a random effect to correct for clustering of piglets within sows.

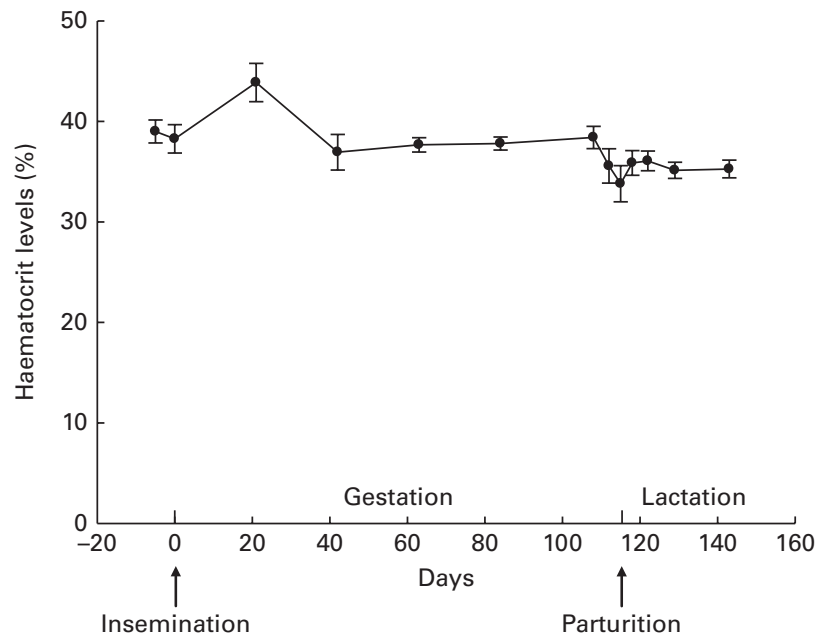

Fig. 1. Haematocrit levels throughout gestation and lactation in sows ( $n$ 15 five primiparous and ten multiparous sows). Values are means, with their standard errors represented by vertical bars. During gestation and lactation, no fluctuation was observed ( $P=0.955$ and $P=0.581$, respectively). 


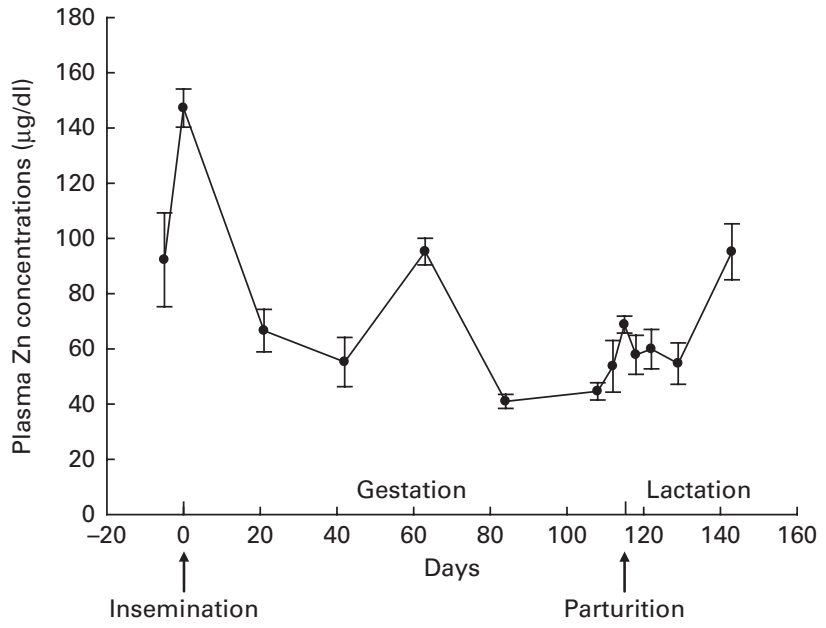

Fig. 2. Plasma zinc concentrations throughout gestation and lactation in sows ( $n$ 15; five primiparous and ten multiparous sows). Values are means, with their standard errors represented by vertical bars. During gestation, plasma zinc concentration decreased linearly after insemination $(P<0.001)$ and increased quadratically towards parturition $(P<0.001)$. During lactation, plasma zinc concentration tended to increase quadratically at the end of lactation $(P=0.063)$. To convert values from $\mu \mathrm{g} / \mathrm{dl}$ to $\mu \mathrm{mol} / \mathrm{l}$, multiply by 0.153 .

The analysed data were considered sufficiently normally distributed based on the graphical evaluation (histogram and $Q Q$ plot) of the residuals. In case of post hoc pairwise testing, $P$ values were corrected with the Tukey-Kramer adjustment for multiple comparisons. All analyses were performed using SAS 9.4 (SAS Institute, Inc.).

\section{Results}

The body weight of multiparous sows increased during gestation and decreased after parturition to similar values at weaning of the preceding cycle (Table 3). Primiparous sows showed a lower body weight compared with multiparous sows throughout the reproductive cycle, and had a higher body weight at weaning compared with the start of the study (Table 3).

Back-fat thickness decreased during lactation $(P<0 \cdot 001)$, independently of parity.

No significant parity effect was found in reproductive performances (Table 4).

The haematocrit level (Fig. 1) did not fluctuate significantly throughout gestation $(\beta=0.019, P=0.955)$ and lactation ( $\beta=-0 \cdot 107, P=0 \cdot 581)$, despite the numerically increased percentage at day 21 of gestation. There was also no parity effect for haematocrit during gestation $(P=0.458)$ and lactation $(P=0.955)$. The concentrations of plasma $\mathrm{Zn}(P=0.173$ for gestation and $P=0.389$ for lactation), serum MT $(P=0 \cdot 127$ for gestation and $P=0.514$ for lactation), plasma $\mathrm{Cu}$ ( $P=0.314$ for gestation and $P=0.259$ for lactation) and serum ALP ( $P=0.346$ for gestation and $P=0.738$ for lactation) were not associated with the haematocrit level. Fluctuation in albumin levels tended to be positively associated with the haematocrit level during gestation $(P=0.086)$ and lactation $(P=0 \cdot 049)$.
Despite the parity effect for body weight and a tendency for an interaction between parity and serum albumin concentration during gestation, the fluctuations of the other biomarkers did not differ between the primiparous and multiparous sows. Therefore, average biomarker fluctuations are presented in the figures.

Plasma Zn concentration decreased linearly after insemination $(\beta=-1.934, \quad P<0.001)$ and increased quadratically towards parturition $(\beta=0.012, P<0 \cdot 001)$ (Fig. 2). After parturition, plasma $\mathrm{Zn}$ concentration seemed to first increase, then decrease and increase again during the last $14 \mathrm{~d}$ of the lactation period. However, there was only a tendency for a quadratic time effect for the last $14 \mathrm{~d}$ of lactation $(\beta=0 \cdot 118$, $P=0.063)$. The variation between the sows was high, especially at days $-5,42$ and 112 of gestation, and at weaning (day 143).

A distinct fluctuation in plasma $\mathrm{Cu}$ concentration during gestation was not found $(\beta=0.408, \quad P=0 \cdot 127$; Fig. 3). Plasma $\mathrm{Cu}$ concentration decreased linearly during lactation $(\beta=-6.716, P<0.001)$ and increased quadratically towards weaning $(\beta=0 \cdot 126, P=0 \cdot 024)$.

The total serum albumin concentration tended to decrease linearly during the beginning of gestation, though it tended to decrease less for primiparous sows (tendency for an interaction between parity and day of gestation, $P=0.055$ ). A quadratic time effect was found towards the end of gestation $(\beta=0.000, P<0.001 ;$ Fig. 4). During lactation, serum albumin concentration decreased linearly $(\beta=-0 \cdot 039, P=0 \cdot 018)$.

During gestation, serum MT concentration did not change significantly $(\beta=-0 \cdot 016, P=0 \cdot 162)$ (Fig. 5). Shortly after parturition, MT concentration decreased linearly $(\beta=-0 \cdot 244, P=0 \cdot 001)$ and increased quadratically towards the end of lactation $(\beta=0.007, P<0 \cdot 001)$.

Serum ALP concentration increased linearly at the beginning of gestation $(\beta=0.395, P=0 \cdot 002)$ and decreased quadratically

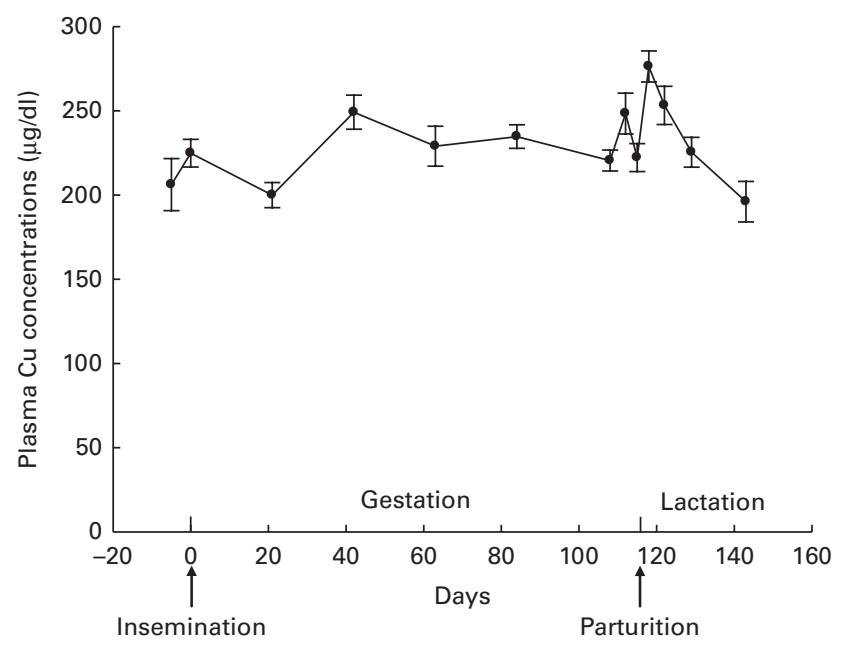

Fig. 3. Plasma copper concentrations throughout gestation and lactation in sows ( $n$ 15; five primiparous and ten multiparous sows). Values are means, with their standard errors represented by vertical bars. During gestation, no fluctuation was observed for plasma copper concentration $(P=0 \cdot 127)$. During lactation, plasma copper concentration decreased linearly $(P<0.001)$ and increased quadratically towards weaning $(P=0.024)$. To convert values from $\mu \mathrm{g} / \mathrm{dl}$ to $\mu \mathrm{mol} / \mathrm{l}$, multiply by $0 \cdot 157$. 


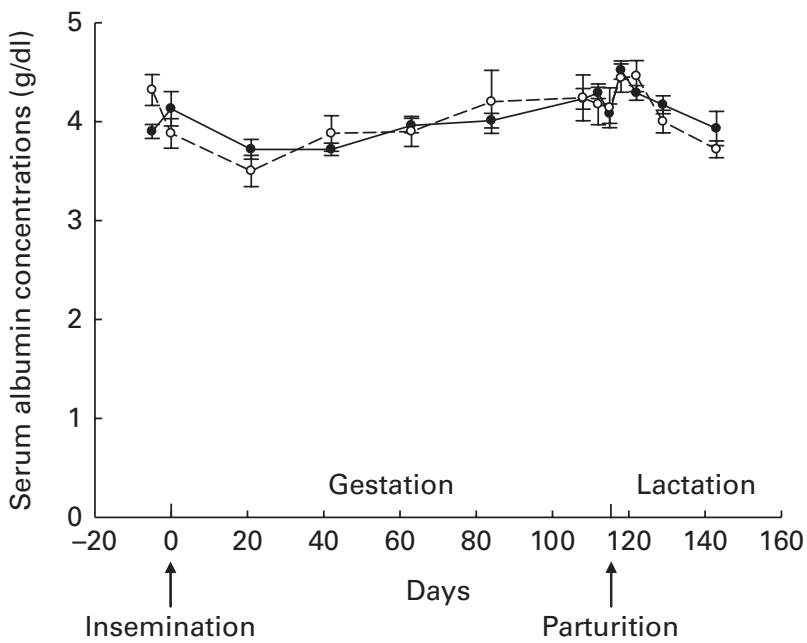

Fig. 4. Total serum albumin concentrations throughout gestation and lacta-

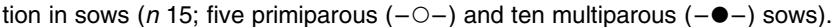
Values are means, with their standard errors represented by vertical bars. During gestation, serum albumin concentration tended to decrease linearly at the beginning of gestation, though tended to decrease less for primiparous sows (tendency for an interaction between parity and day of gestation, $P=0.055)$ and increased quadratically towards the end of gestation $(P<0.001)$. During lactation, serum albumin concentration decreased linearly $(P=0.018)$. To convert values from $\mathrm{g} / \mathrm{dl}$ to $\mu \mathrm{mol} / \mathrm{l}$, multiply by 10 .

towards parturition ( $\beta=-0.003, P=0 \cdot 001$ ) (Fig. 6). During the lactation period, no significant fluctuations were observed in ALP concentration $(\beta=0.859, P=0 \cdot 140)$. No parity effect was found, despite the numerically higher serum ALP concentrations of primiparous sows throughout the reproductive cycle ( $P=0.102$ for gestation and $P=0.473$ for lactation).

\section{Biomarkers in piglets' plasma, colostrum and milk}

No significant parity effects were found for piglet body weight, haematocrit level, plasma $\mathrm{Zn}$ and $\mathrm{Cu}$ concentrations, placental weight, colostrum $\mathrm{Zn}$ and $\mathrm{Cu}$ concentrations, and milk $\mathrm{Zn}$ concentration ( $P>0.050$; Table 5$)$. Milk Cu concentration tended to be lower for primiparous sows than for multiparous sows $(\beta=-0.378, P=0.099)$.

At parturition, serum albumin concentration of the sow tended to be associated with the average body weight of her piglets born alive $(\beta=0 \cdot 297, P=0 \cdot 060)$.

Plasma $\mathrm{Zn}$ concentration of the piglets was associated with serum MT concentration of the sow during gestation and at parturition $(\beta=11.891, P=0.036$ and $\beta=14.261, P=0.028$, respectively) and associated with the haematocrit level of piglets $(\beta=-1.732, P=0.032)$.

\section{Discussion}

Fluctuations of $\mathrm{Zn}$ status biomarkers during gestation and lactation differed distinctly between biomarkers and were independent of parity (except for serum albumin). These differences are probably related to the respective roles of these biomarkers in $\mathrm{Zn}$ homeostasis throughout the different phases of the reproductive cycle, as has been shown in other animal species and human subjects. However, the observed evolution over time might have been partly influenced by random period effects, such as temperature.

During gestation, $\mathrm{Zn}$ requirements are increased to support embryogenesis and fetal growth and development ${ }^{(1-4,23,24)}$, resulting in homeostatic adjustments to (re)distribute more $\mathrm{Zn}$ to maternal tissues (e.g. placenta, liver and bone) and to the fetus ${ }^{(23-26)}$. This $\mathrm{Zn}$ sequestration to maternal tissues and the fetus may decrease the total circulating $\mathrm{Zn}$ concentration $^{(24)}$

In the present study, plasma Zn concentration decreased during gestation as hypothesised based on other studies in sows ${ }^{(27-29)}$. This conceivably reflects the increased intracellular $\mathrm{Zn}$ need to protect maternal erythrocytes from oxidative stress, thereby increasing erythrocyte $\mathrm{Zn}$ and MT concentrations (due to the synthesis of carbonic anhydrase) and decreasing plasma $\mathrm{Zn}$ concentrations ${ }^{(24,25,30)}$.

$\mathrm{Zn}$ is predominantly bound to albumin after absorption and has a high affinity to albumin ${ }^{(15,16)}$. A lower $\mathrm{Zn}$ fraction bound to albumin or a lower affinity of $\mathrm{Zn}$ for albumin was mentioned to explain the decreased plasma $\mathrm{Zn}$ concentration. Interestingly, the total serum albumin concentration in the present study increased during gestation, hence not reflecting the decline in $\mathrm{Zn}$ concentration, as expected and as has been found in other studies in women ${ }^{(3,31)}$.

Whereas albumin serves as an important $\mathrm{Zn}$ transporter, MT is involved in $\mathrm{Zn}$ transfer within the intestinal mucosal cell, regulating the quantity of $\mathrm{Zn}$ absorbed ${ }^{(15,17,18)}$. When $\mathrm{Zn}$ is bound to albumin in plasma and entering the liver, MT is synthesised. MT in the liver removes $\mathrm{Zn}$ from the plasma and redistributes it to various tissues ${ }^{(15,23,32)}$. Hepatic MT synthesis is influenced by dietary $\mathrm{Zn}$ intake as well as plasma $\mathrm{Zn}$ concentrations $^{(15,17,33,34)}$, suggesting that serum MT concentration reflects $\mathrm{Zn}$ absorption. This is confirmed in the present study, where serum MT concentration fluctuated similarly to plasma

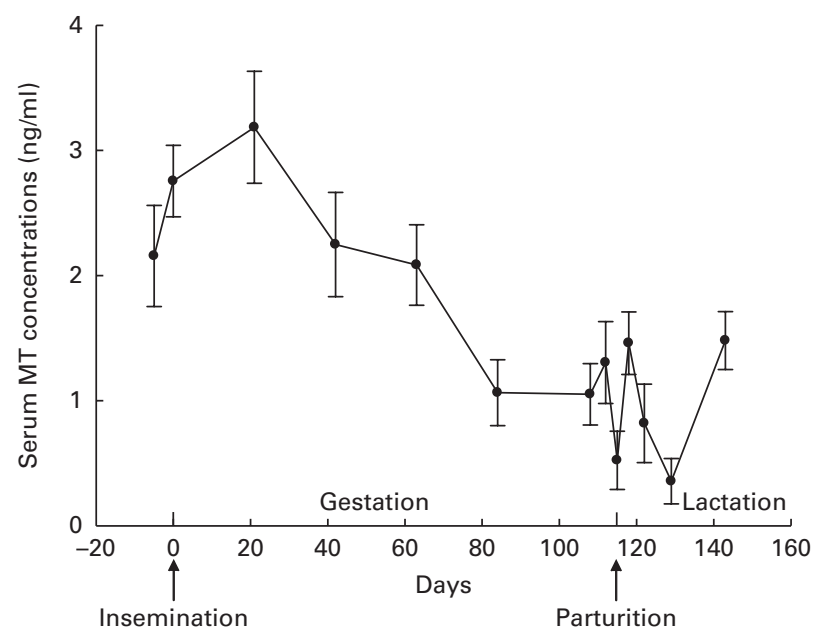

Fig. 5. Serum metallothionein (MT) concentrations throughout gestation and lactation in sows ( $n$ 15; five primiparous and ten multiparous sows). Values are means, with their standard errors represented by vertical bars. During gestation, no fluctuation was observed for serum MT concentration $(P=0.162)$. During lactation, serum MT concentration decreased linearly $(P=0.001)$ and increased quadratically towards the end of lactation $(P<0.001)$. 


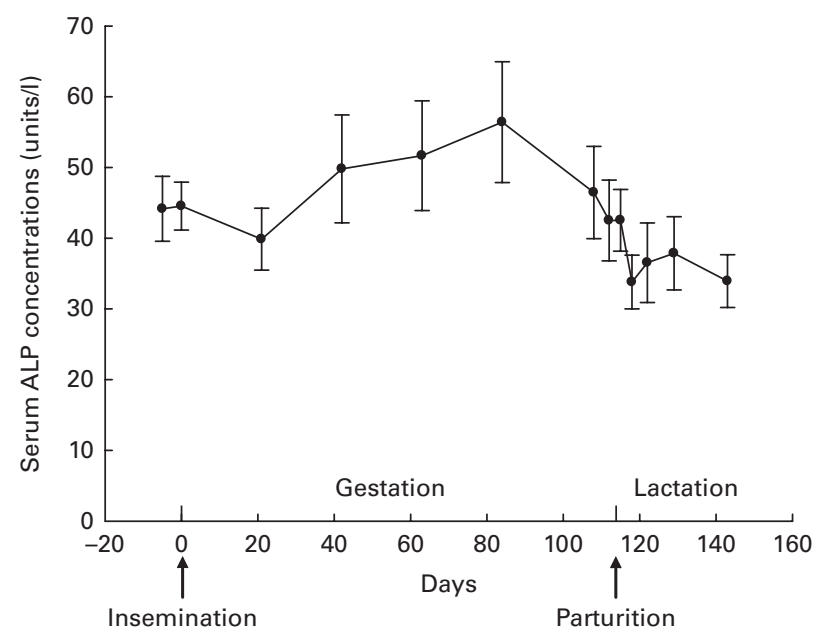

Fig. 6. Serum alkaline phosphatase (ALP) concentrations throughout gestation and lactation in sows ( $n$ 15; five primiparous and ten multiparous sows). Values are means, with their standard errors represented by vertical bars. During gestation, serum ALP concentration first increased linearly $(P=0.002)$ and decreased quadratically towards parturition $(P=0.001)$. During lactation, no fluctuation was observed for serum ALP concentration $(P=0 \cdot 140)$.

Zn concentrations during gestation but not at parturition when dietary $\mathrm{Zn}$ intake was low.

Plasma Cu can be bound to MT as well, but fluctuations in plasma $\mathrm{Cu}$ concentration in the present study are comparable with other studies in sows ${ }^{(29,33)}$, women ${ }^{(35)}$ and ewes ${ }^{(36)}$, and therefore suggests that plasma $\mathrm{Cu}$ was not interfering with the fluctuation of serum MT. This was also observed in the study by López-Alonso et al. ${ }^{(37)}$, where liver and kidney MT concentrations were highly dependent on the $\mathrm{Zn}$ status of the pig, and neither $\mathrm{Cu}$ nor $\mathrm{Cd}$ displaced $\mathrm{Zn}$ from MT.

ALP is found in the blood and bone and is involved in the formation of hydroxyapatite ${ }^{(16,38)}$, which is important for regulating ordered mineral deposition during bone formation $^{(38-40)}$. ALP concentration increased during gestation and decreased towards parturition in the present study. This fluctuation may indicate that ALP is related to bone formation in the process of bone remodelling.

During lactation, $\mathrm{Zn}$ requirements are increased to support milk synthesis and secretion ${ }^{(24)}$, resulting in a (re)distribution of $\mathrm{Zn}$ to the mammary gland. This occurs by mobilising $\mathrm{Zn}$ from involuting tissues (uterus) and maternal blood after parturition, mobilisation from the bone, and by increased efficiency of $Z n$ absorption in the intestine ${ }^{(24-26,41,42)}$. The distribution of $\mathrm{Zn}$ to the mammary gland may affect $\mathrm{Zn}$-related blood parameters differently than during gestation ${ }^{(24)}$.

Towards the end of lactation, plasma $\mathrm{Zn}$ concentrations in the present study seemed to return to initial values at early gestation, probably resulting from increased absorption or decreased nutrient requirements ${ }^{(24,43)}$. These plasma Zn fluctuations during lactation correspond to other studies in sows $^{(29)}$, women $^{(2)}$ and sheep ${ }^{(4)}$, except for the study by Kalinowski \& Chavez ${ }^{(28)}$, who did not observe an increase in plasma $\mathrm{Zn}$ concentration during lactation in sows. However, in that study, no blood samples were analysed after 2 weeks of lactation.
Similarly to fluctuation in serum albumin concentrations during gestation, total serum albumin concentrations did not reflect the changes in plasma $\mathrm{Zn}$ concentration during lactation in the present study: the increase in plasma $\mathrm{Zn}$ concentrations coincided with an increase in serum albumin concentrations. $\mathrm{Zn}$ is then rapidly removed from albumin and transferred to other tissues, thereby ensuring the capacity to maintain $\mathrm{Zn}$ homeostasis. However, this was not demonstrated in the present study or other studies in women ${ }^{(3,31)}$.

Serum MT concentrations increased at the end of lactation in the present study. This increase agrees with increased $\mathrm{Zn}$ absorption, in which more plasma $\mathrm{Zn}$ enters the liver where hepatic MT is synthesised to sequester $\mathrm{Zn}$ from the plasma to the tissues.

The fact that plasma $\mathrm{Cu}$ concentrations decreased towards the end of lactation, as opposed to plasma $\mathrm{Zn}$ concentrations, demonstrates that plasma mineral concentrations probably reflect dietary intakes. $\mathrm{Zn}$ is an important antagonist of $\mathrm{Cu}$, hence the rise in plasma $\mathrm{Zn}$ concentrations towards the end of lactation combined with a decrease in plasma $\mathrm{Cu}$ concentrations seems logical and corresponds to other studies in sows $^{(28,29)}$ and ewes ${ }^{(36)}$.

The mobilised and absorbed $\mathrm{Zn}$ will be used for milk production to provide $\mathrm{Zn}$ to the piglets. Plasma $\mathrm{Zn}$ concentration in piglets before colostrum intake may reflect the dietary $\mathrm{Zn}$ intake levels of sows during gestation ${ }^{(1,16,45-47)}$. However, in the present study, maternal plasma $\mathrm{Zn}$ concentration was not associated with the piglets' plasma $\mathrm{Zn}$ concentration. Interestingly, maternal serum MT concentration was significantly associated with the piglets' plasma $\mathrm{Zn}$ concentration: higher MT concentrations in sows during gestation and at parturition increased plasma $\mathrm{Zn}$ concentration in the piglets' plasma.

Additionally, fluctuations of $\mathrm{Zn}$ status biomarkers may identify critical periods throughout the reproductive cycle during which high $\mathrm{Zn}$ requirements are not met by dietary

Table 5. Piglets' indicatives* (n 30) and colostrum and milk zinc and copper concentrations

(Mean values with their standard errors)

\begin{tabular}{|c|c|c|c|c|c|}
\hline & \multicolumn{2}{|c|}{ Primiparous } & \multicolumn{2}{|c|}{ Multiparous } & \multirow[b]{2}{*}{$P$} \\
\hline & Mean & SE & Mean & SE & \\
\hline BW (kg) & 1.5 & 0.1 & 1.6 & 0.1 & 0.172 \\
\hline HCt level (\%) & $37 \cdot 9$ & $2 \cdot 0$ & 41.6 & $1 \cdot 2$ & 0.676 \\
\hline Plasma Zn & & & & & 0.268 \\
\hline$\mu \mathrm{g} / \mathrm{dl}$ & $73 \cdot 0$ & $8 \cdot 9$ & $60 \cdot 7$ & $5 \cdot 9$ & \\
\hline$\mu \mathrm{mol} / \mathrm{l}$ & $11 \cdot 2$ & 1.4 & $9 \cdot 3$ & 0.9 & \\
\hline Plasma Cu & & & & & 0.888 \\
\hline$\mu \mathrm{g} / \mathrm{dl}$ & $12 \cdot 6$ & $1 \cdot 2$ & $15 \cdot 6$ & $2 \cdot 1$ & \\
\hline$\mu \mathrm{mol} / \mathrm{l}$ & $2 \cdot 0$ & 0.2 & $2 \cdot 4$ & 0.3 & \\
\hline Placental weight (kg) & $2 \cdot 6$ & 0.5 & 2.7 & 0.2 & 0.951 \\
\hline \multicolumn{6}{|l|}{ Colostrum $(\mathrm{mg} / \mathrm{kg})$} \\
\hline $\mathrm{Zn}$ & $18 \cdot 4$ & $2 \cdot 0$ & $16 \cdot 2$ & $1 \cdot 2$ & 0.529 \\
\hline $\mathrm{Cu}$ & 4.5 & 0.2 & $4 \cdot 4$ & 0.3 & 0.564 \\
\hline \multicolumn{6}{|l|}{ Milk (mg/kg) } \\
\hline $\mathrm{Zn}$ & 6.7 & 0.2 & $6 \cdot 6$ & 0.2 & 0.948 \\
\hline $\mathrm{Cu}$ & $1 \cdot 1$ & 0.1 & 1.4 & 0.1 & 0.099 \\
\hline
\end{tabular}

BW, body weight; $\mathrm{HCt}$, haematocrit.

*Piglets' BW, HCt, and plasma Zn and Cu concentrations were from two randomly selected piglets per sow at parturition (day 115) before colostrum intake. 
$\mathrm{Zn}$ intake. It has been shown that $\mathrm{Zn}$ deficiency during gestation may affect the growth and development of the fetus, induce complications at birth, and limit the metabolic adaptation capacity of the sow ${ }^{(35,48-50)}$.

In the literature, marginal values for plasma/serum Zn concentrations for pigs have been suggested ${ }^{(51)}$, with a lower limit of normality of $60 \mu \mathrm{g} / \mathrm{dl}(9 \cdot 2 \mu \mathrm{mol} / \mathrm{l})$ and a normal marginal range for mean serum concentrations between 40 and $70 \mu \mathrm{g} / \mathrm{dl}(6 \cdot 1-10 \cdot 7 \mu \mathrm{mol} / \mathrm{l})$. In the present study, the average plasma $\mathrm{Zn}$ concentration was $71.5 \mu \mathrm{g} / \mathrm{dl} \quad(10.9 \mu \mathrm{mol} / \mathrm{l})$ during gestation and $66.9 \mu \mathrm{g} / \mathrm{dl}(10 \cdot 2 \mu \mathrm{mol} / \mathrm{l})$ during lactation. The sows in the present study had on average sufficient plasma Zn levels. However, at days 42, 84, 108, 112, 118, 122 and 129, the average plasma $\mathrm{Zn}$ concentrations were below the normal range defined by Suttle ${ }^{(51)}$, though sows can replace their $\mathrm{Zn}$ stores towards weaning. The dietary $\mathrm{Zn}$ concentration was above the $\mathrm{Zn}$ requirements, and no conclusion can be drawn for the presence of marginal $\mathrm{Zn}$ deficiency. Furthermore, plasma $\mathrm{Zn}$ concentrations varied widely among sows, which also hampers sound conclusions in individual sows.

\section{Conclusion}

Zn status shows distinct fluctuations throughout the reproductive cycle of sows, independently of parity. However, this $\mathrm{Zn}$ status pattern differs according to the chosen $\mathrm{Zn}$ status biomarker. Therefore, assessing $\mathrm{Zn}$ status in breeding sows should best be determined with multiple biomarkers. For the present study, a combination of plasma $\mathrm{Zn}$ and serum MT seemed most suitable to assess the Zn status.

Sound conclusions regarding critical periods for $\mathrm{Zn}$ status throughout the reproductive cycle in sows could not be distinguished in the present study. For future studies, it is good to take into account that fluctuations in plasma $\mathrm{Zn}$ concentrations over a reproductive cycle are noticeable. After periods of lower plasma $\mathrm{Zn}$ concentration at the end of gestation and throughout lactation, plasma $\mathrm{Zn}$ concentrations increase towards weaning.

\section{Acknowledgements}

The authors thank the technicians $M$. van Yperen and T. Martens, animal caretakers of the ILVO experimental farm, and colleagues who were 'sow sitting' for the wonderful assistance and support. The authors also thank M. Levenson for English-language editing.

The present study, part of the postgraduate study of the first author, was supported by the Institute for Promotion of Innovation through Science and Technology in Flanders (IWT, grant no. 090938), and co-funded by Orffa, VDV Beton, Boerenbond, AVEVE, INVE and Boehringer Ingelheim. These funders had no role in the design and analysis of the study or in the writing of this article.

The authors' contributions are as follows: G. P. J. J. and S. M. were supervisors; G. P. J. J., S. M., F. A. M. T. and D. M. were involved in the writing of the research proposal; K. C. M. L., E. N., A. C. and G. D. L. contributed to the practical work, including the analyses of some biomarkers; B. A. provided guidance for the statistical analyses. All authors examined the article critically and added insightful and useful comments to the final version of the manuscript.

None of the authors has any conflict of interest to declare.

\section{References}

1. Mahan DC (1990) Mineral nutrition of the sow: a review. J Anim Sci 68, 573-582.

2. Donangelo CM, Vargas Zapata CL, Woodhouse LR, et al. (2005) Zinc absorption and kinetics during pregnancy and lactation in Brazilian women. Am J Clin Nutr 82, 118-124.

3. Maia PA, Figueiredo RCB, Anastácio AS, et al. (2007) Zinc and copper metabolism in pregnancy and lactation of adolescent women. Nutrition 23, 248-253.

4. Caulfield LE, Donangelo CM, Chen P, et al. (2008) Red blood cell metallothionein as an indicator of zinc status during pregnancy. J Nutr 24, 1081-1087.

5. Perveen S, Altaf W, Vohra N, et al. (2002) Effect of gestational age on cord blood plasma copper, zinc, magnesium and albumin. Early Hum Dev 69, 15-23.

6. Smith OB \& Akinbamijo OO (2000) Micronutrients and reproduction in farm animals. Anim Reprod Sci 60-61, 549-560

7. Ashworth CJ \& Antipatis C (2001) Micronutrient programming of development throughout gestation. Reproduction 122, 527-535.

8. Vazquez-Armijo JF, Rojo R, Salem AZM, et al. (2011) Trace elements in sheep and goats reproduction: a review. Trop Subtrop Agroecosyst 14, 1-13.

9. Apgar J \& Fritzgerald JA (1987) Measures of zinc status in ewes given a low zinc diet throughout pregnancy. Nutr Res 7, 1281-1290.

10. Wood RJ (2000) Assessment of marginal zinc status in humans. J Nutr 130, 1350S-1354S.

11. Hambidge M (2003) Biomarkers of trace mineral intake and status. J Nutr 133, 948S-955S.

12. Lowe NM, Woodhouse LR, Sutherland B, et al. (2004) Kinetic parameters and plasma zinc concentration correlate well with net loss and gain of zinc from men. J Nutr 134, $2178-2181$.

13. Fairweather-Tait SJ, Harvey LJ \& Ford D (2008) Does aging affect zinc homeostasis and dietary requirements? Exp Gerontol 43, 382-388.

14. Lowe NM, Fekete K \& Decsi T (2009) Methods of assessment of zinc status in humans: a systematic review. Am J Clin Nutr 89, 2040S-2051S.

15. McDowell LR (2003) Zinc. In Minerals in Animal and Human Nutrition, 2nd ed., pp. 357-396. Amsterdam: Elsevier Science B.V.

16. Peters JC (2006) Evaluating the efficacy of dietary organic and inorganic trace minerals in reproducing female pigs on reproductive performance and body mineral composition. PhD Thesis, Ohio State University.

17. Cousins RB (1996) Zinc. In Present Knowledge of Nutrition, 7th ed., pp. 293-306 [LJ Filer and EE Ziegler, editors]. Washington, DC: ILSI Press.

18. Bikker P \& Jongbloed AW (2014) Koper- en zinknormen voor varkens (Copper and zinc standards pigs). In Rapport 746 (Report 746). Wageningen: Wageningen UR Livestock Research.

19. Coleman JE (1992) Zinc proteins: enzymes, storage proteins, transcription factors, and replication proteins. Annu Rev Biochem 61, 897-946. 
20. NRC (1998) Nutrient Requirements of Swine, 10th ed. Washington, DC: National Academy Press.

21. Milne DB, Davies CD \& Nielsen FH (2001) Low dietary zinc alters indices of copper function and status in postmenopausal women. Nutrition 17, 701-708.

22. EFSA Panel on Additives and Products or Substances used in animal feed (2014) Scientific opinion on the potential reduction of the currently authorized maximum zinc content in complete feed. EFSA J 12, 3668.

23. King JC (2000) Determinants of maternal zinc status during pregnancy. Am J Clin Nutr 71, 1334S-1343S.

24. Donangelo CM \& King JC (2012) Maternal zinc intake and homeostatic adjustments during pregnancy and lactation. Nutrients 4, 782-798.

25. Tamura T \& Goldenberg RL (1996) Zinc nutriture and pregnancy outcome. Nutr Res 16, 139-181.

26. Krebs NF (1998) Zinc supplementation during lactation. $\mathrm{AmJ}$ Clin Nutr 68, 509S-5512.

27. Hill GM, Miller ER \& Stowe HD (1983) Effect of dietary zinc levels on health and reproductivity of gilts and sows through two parities. J Anim Sci 57, 114-122.

28. Kalinowski J \& Chavez ER (1984) Effect of low dietary zinc during late gestation and early lactation on the sow and neonatal piglets. Can J Anim Sci 64, 749-758.

29. Girard CL, Robert S, Matte JJ, et al. (1996) Serum concentrations of micronutrients, packed cell volume, and blood hemogloblin during the first two gestations and lactations of sows. Can J Vet Res 60, 179-185.

30. Caulfield LE, Zavaleta N \& Figueroa A (1999) Adding zinc to prenatal iron and folate supplements improves maternal and neonatal zinc status in a Peruvian population. Am J Clin Nutr 69, $1257-1263$.

31. Hambidge KM, Krebs NF, Jacobs MA, et al. (1983) Zinc nutritional status during pregnancy: a longitudinal study. Am J Clin Nutr 37, 429-442.

32. Bremner I (1993) Metallothionein in copper deficiency and toxicity. In Proceedings of the Eighth International Symposium on Trace Elements in Man and Animals, pp. 507-515 [M Anke, D Meissner and CF Mills, editors]. Gersdorf: Verlag Media Touristik.

33. Richards MP (1999) Zinc, copper, and iron metabolism during porcine fetal development. Biol Trace Elem Res 69 , $27-44$.

34. Gibson RS (2005) Metallothionein. In Principles of Nutritional Assessment, 2nd ed., p. 726. New York: Oxford University Press.

35. Álvarez SI, Castañón SG, Ruata MLC, et al. (2007) Updating of normal levels of copper, zinc and selenium in serum of pregnant women. J Trace Elem Med Bio 21, 49-52.
36. Elnageeb ME \& Adelatif AM (2010) The minerals profile in desert ewes (Ovis aries): effect of pregnancy, lactation and dietary supplementation. Am Eurasian J Agric Environ Sci 7, 18-30.

37. López-Alonso $\mathrm{M}$, Benedito JL, Garcia-Vaquero $\mathrm{M}$, et al. (2012) The involvement of metallothionein in hepatic and renal $\mathrm{Cd}, \mathrm{Cu}$ and $\mathrm{Zn}$ accumulation in pigs. Livest Sci $\mathbf{1 5 0}$, $152-158$.

38. van Riet MMJ, Millet S, Aluwé M, et al. (2013) Impact of nutrition on lameness and claw health in sows. Livest Sci 156, $24-35$.

39. Ruz M, Cavan KR, Bettger WJ, et al. (1992) Erythrocytes, erythrocyte membranes, neutrophils and platelets as biopsy materials for the assessment of zinc status in humans. $\mathrm{Br} \mathrm{J}$ Nutr 68, 515-527.

40. Clarke B (2008) Normal bone anatomy and physiology. Clin J Am Soc Nephrol 3, S131-S139.

41. Swanson CA \& King JC (1983) Reduced serum zinc concentration during pregnancy. Obstet Gynecol 62, 313-318.

42. Moser-Veillon PB (1995) Zinc needs and homeostasis during lactation. Analyst 120, 895-897.

43. Liesegang A, Risteli J \& Wanner M (2006) The effects of first gestation and lactation on bone metabolism in dairy goats and milk sheep. Bone 38, 794-802.

44. Gürdoğan F, Yildiz A \& Balikci E (2006) Investigation of serum $\mathrm{Cu}, \mathrm{Zn}, \mathrm{Fe}$ and Se concentrations during pregnancy (60, 100 and 150 days) and after parturition (45 days) in single and twin pregnant sheep. Turk J Vet Anim Sci 30, 61-64.

45. Henkin RI, Marshall JR \& Meret S (1971) Maternal and foetal metabolism of copper and zinc at term. Am J Obstet Gynecol 110, 131-135.

46. Dreosti IE, McMichael AJ, Gibson GT, et al. (1982) Fetal and maternal serum copper and zinc levels in human pregnancy. Nutr Res 2, 591-602.

47. Hill GM, Miller ER, Whetter PA, et al. (1983b) Concentration of minerals in tissues of pigs from dams fed different levels of dietary zinc. J Anim Sci 57, 130-138.

48. Cherry FF, Bemnett EA, Bazzano GS, et al. (1981) Plasma zinc in hypertension/toxemia and other reproductive variables in adolescent pregnancy. Am J Clin Nutr 34, $2367-2375$.

49. Swanson CA \& King JC (1987) Zinc and pregnancy outcome. Am J Clin Nutr 46, 763-771.

50. Apgar J \& Fitzgerald JA (1985) Effect on the ewe and lamb of low zinc intake throughout pregnancy. J Anim Sci 60, $1530-1538$.

51. Suttle NF (2010) Zinc. In Mineral Nutrition of Livestock, 4th ed., pp. 426-458. Wallingford: CABI. 